\title{
PROBLEMS IN THE MEASUREMENT, CALIBRATION, ANALYSIS, AND COMMUNICATION OF RADIOCARBON DATES (WITH SPECIAL REFERENCE TO THE PREHISTORY OF THE AEGEAN WORLD)
}

\author{
Malcolm H Wiener \\ Institute for Aegean Prehistory, 66 Vista Drive, Greenwich, Connecticut 06830-7128, USA. \\ Email: mhwiener@villacandia.com.
}

\begin{abstract}
Radiocarbon dating encounters (1) problems of reservoir effects and regional/seasonal variation affecting the chronological reliability of measurements, (2) problems of calibration of measurements via comparison with tree segments of known dendrochronological dates, (3) problems of statistical inference with respect to the data pre- and post-calibration, and (4) problems of the analysis and communication of information to archaeologists, historians, and other interested parties. This paper considers the special characteristics of each of the problem areas indicated in order to improve communication between

${ }^{14} \mathrm{C}$ scientists and the disciplines of archaeology, anthropology, and ancient history.
\end{abstract}

\section{INTRODUCTION}

The dating of critical events and periods in premodern history and prehistory may be of critical importance to our understanding of the human past. Discussion of the date of the great Late Bronze Age volcanic eruption on the island of Thera in the Aegean is but one example. Radiocarbon analysis now plays a major role in dating, together with texts, archaeological stratification, astronomical observations, and dendrochronology. Problems arise when sets of ${ }^{14} \mathrm{C}$ dates differ with respect to the same reign or period, when ${ }^{14} \mathrm{C}$ dates are inconsistent with historical records or other scientific dating methods, or when misunderstandings arise with regard to the accuracy and precision of ${ }^{14} \mathrm{C}$ dates, either in general or in specific instances. This article seeks to identify the principal sources of uncertainty and of miscommunication between ${ }^{14} \mathrm{C}$ scientists and those who submit samples for measurement plus the world at large.

\section{PROBLEMS AFFECTING THE CHRONOLOGICAL RELIABILITY OF MEASUREMENTS}

Problems include (1) the presence of unexplained outliers and sporadic differences in measurements of samples divided between labs; (2) regional/seasonal differences in measurements of material from different locations but of the same known dendrochronological date; and (3) the distorting effect of the presence of ${ }^{14} \mathrm{C}$-deficient carbon ("old carbon") in a sample, which results in ${ }^{14} \mathrm{C}$ measurements providing dates older than true dates.

(1) The last decade has seen marked improvement in the consistency of measurements of samples divided between certain high-precision laboratories, but occasional problems persist (Taylor 1997; Bruins et al. 2003; Reimer et al. 2004). Measurements made more than $5 \mathrm{yr}$ ago may pose significant problems in this respect. For example, Manning et al. (2006b) reported that

[o]verall, comparing the Oxford versus Vienna data on the same samples..., we find an average offset of $-11.4{ }^{14} \mathrm{C}$ years. The standard deviation is, however, rather larger than the stated errors on the data would imply at 68.1 [uncalibrated radiocarbon years]. This indicates that there is an unknown error component of $54.5^{14} \mathrm{C}$ years.

Past problems, sometimes stemming from inadequate pretreatment procedures, may be embedded in databases that include both recent and older measurements, as in the "Thera 28 dataset," which includes measurements from the 1970s through 2004 (Scott 2003; Reimer et al. 2004; Manning et al. 2006a: especially Figure $2 \mathrm{~b}$ caption; 2006b). In practice, it is often difficult to identify and remove measurements affected by inadequate past pretreatment procedures.

C 2012 by the Arizona Board of Regents on behalf of the University of Arizona

Proceedings of the 6th International Radiocarbon and Archaeology Symposium, edited by E Boaretto and N R Rebollo Franco RADIOCARBON, Vol 54, Nr 3-4, 2012, p 423-434 
(2) Both general regional and seasonal regional differences in ${ }^{14} \mathrm{C}$ measurements for the same known dendrochronologically dated specimens have been shown to exist (McCormac et al. 1995; Keenan 2004). A separate calibration curve for the last millennium has been developed for the Southern Hemisphere reflecting regional differences on a hemispheric scale (McCormac et al. 2004). Regional/seasonal effects have long been suspected (Levin et al. 1992; Housley et al. 1999: 166-7; Levin and Hesshaimer 2000) in view of differences in measurements of sections of a single year ring of a tree of between 8 and $32 \mathrm{yr}$ between the winter low and summer high, with a mean standard deviation of $14 \mathrm{yr}$ (but dismissed as not significant by others-see e.g. Manning et al. 2009: 305). A recent study comparing seeds collected by English botanists over centuries beginning in AD 1700 from Egypt, where the peak growing season is typically January-February, with the calibration curve oaks from western Europe, where the main growth occurs in summer, showed an average offset of $19.5 \pm 5$ calibrated yr (Dee 2010). Serious regional differences exist between ${ }^{14} \mathrm{C}$ measurements of the Gordion logs of the Anatolian floating tree-ring chronology and those of German and Irish trees on which the calibration curve is based in the 9th-8th centuries BC (Kromer et al. 2001). The result has been attributed to "an enhanced seasonal ${ }^{14} \mathrm{CO}_{2}$ cycle, with seasonally peaked flux of stratospheric ${ }^{14} \mathrm{C}$ into the troposphere during periods of low solar magnetic activity, coinciding with substantial atmospheric cooling," resulting in later growing seasons in Anatolia in this period (Kromer et al. 2001:2529). Unresolved disparities in measurements of trees of known dendrochronological date occur among logs from the same site (e.g. Gordion in Turkey for the years 1580,1570 , and $1560 \mathrm{BC}$ ), among trees in the same geographic area (for example, 2 forests near the Rhine River at 1550 BC) (Kromer et al. 2010: especially Figures 2 and 5), and between the trees from Germany that form the backbone of the calibration curve and the trees from Gordion in Turkey in a number of periods (e.g. $\sim 1325$ and $1225 \mathrm{BC}, 1080-990 \mathrm{BC}$ and especially between 850 and $750 \mathrm{BC}$, when the average offset is $28.8 \pm 26.3{ }^{14} \mathrm{C}$ yr [Manning et al. 2010:1593-4]). (It should be borne in mind that the Anatolian dendrochronology is floating to a limited extent, relating to the continuous European chronology via a terminus in a context datable historically to within about a decade, and supported by a wiggle-match over centuries [Manning et al. 2001].) Such effects of regional offsets are clearly illustrated in Figure 1 . Of course, some variation in ${ }^{14} \mathrm{C}$ measurements of material of the same calendar date is to be expected given the inherent characteristics of the measurement process, but when repeated measurements produce marked differences, it is likely that at least one of the measurements in question has been affected by one or more of the problems discussed in this paper or by a yet unknown cause.

(3) A major problem of measurement in some areas is the reservoir effect of the presence of old carbon from (a) gas emission fields including those near volcanoes; (b) water that has been in contact with carbonate rocks and is absorbed by plants or consumed by living creatures (the hardwater effect); (c) the upwelling of deep ocean water in the vicinity of the samples measured; or (d) seawater in estuaries or lagoons that in turn may affect ${ }^{14} \mathrm{C}$ measurements from seeds of plants in the immediate vicinity.

(a) The problem of gas emissions, and in particular those emanating from the vicinity of volcanoes, has long troubled Mediterranean chronology. In Italy, the area of $\mathrm{CO}_{2}$ emissions stretches from Florence to Naples and from the Tyrrhenian Sea to the Apennines (Frezzotti et al. 2009:109). Similar phenomena have been observed in areas of southern Italy. Reported ${ }^{14} \mathrm{C}$ dates from Italian sites whose historical contexts are clear are frequently 100-300 yr too early (Rogie 1996; Minissale et al. 1997; Chiodini et al. 1999, 2004; Rogie et al. 2000; Cardellini et al. 2003; Gambardella et al. 2004). A similar phenomenon is reported with regard to Iceland, where volcanic/geothermal effects are thought to be the cause of ${ }^{14} \mathrm{C}$ dates $100-200$ yr earlier than presumed historical dates for the earliest European occupation levels (Sveinbjörnsdóttir and Heinemeier 2011). 


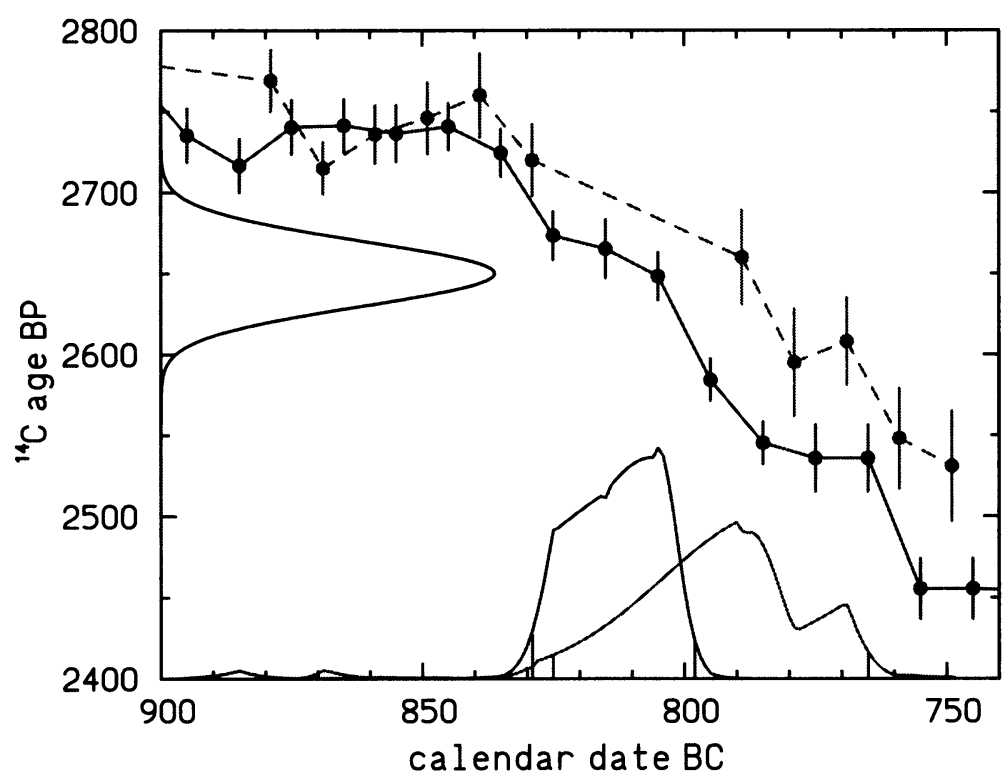

Figure 1 The importance of regional ${ }^{14} \mathrm{C}$ offsets is illustrated by this calibration of a hypothetical ${ }^{14} \mathrm{C}$ age of $2650 \pm 20{ }^{14} \mathrm{C}$ yr before the present (BP) (black) with the Northern Hemisphere calibration data set (blue data points) and the Anatolian tree-ring sequence (red data points). The $2 \sigma$ calibrated age ranges for the resulting probability distributions are 829 to $798 \mathrm{BC}$ and 825 to $765 \mathrm{BC}$, respectively. Calibration was done with CALIB v 4.3 (Reimer 2001: Figure 2). The online edition of this article contains the fullcolor version of this figure.

Volcanic landscapes create particular problems. On the volcanic island of Stromboli, diffuse deep magmatic $\mathrm{CO}_{2}$ degassing structures have been identified over much of the island (Carapezza et al. 2009). Similar effects have been reported from the vicinity of the Sulphur Banks Volcano in Hawaii and 2 temple sites in Cambodia (Wiener 2010:371-2 and references therein). It is all the more surprising, therefore, to encounter statements denying any likelihood of a similar effect with regard to the dating of the great Late Bronze Age volcanic eruption on the island of Thera. It has been asserted (Bruns et al. 1980; Shore et al. 1995; Pasquier-Cardin et al. 1999; Manning et al. 2009:301) that winds quickly dissipate volcanic emissions, as if a claim had been made that volcanic emissions from volcano cones were the problem, rather than emissions from line (fault) or diffuse area (soil) sources (or from upwelling of seawater or irrigation from rivers in contact with carbonate rocks). It is equally surprising to encounter the statement (sans citation) that plants and trees do not absorb carbon through their roots but only through their leaves (Friedrich et al. 2009:296), when a number of major studies have shown just the opposite (Stolwijk and Thimann 1957; Skok et al. 1962; Geisler 1963; Splittstoesser 1966; Arteca et al. 1979; Yorgalevitch and Janes 1988; Cramer 2002; Ford et al. 2007). The possibility of reservoir effects in the case of the Santorini eruption has also been denied on the ground that such effects would necessarily be highly irregular, unlike the Theran measurements in question, which are said to fall in a tight range (Manning et al. 2009:300). In fact, measurements of seeds from the same location in the final destruction horizon produced ages with central dates as much as $250 \mathrm{yr}$ apart (with seeds of the same species providing central dates $215 \mathrm{yr}$ apart) and no information was provided with respect to whether any measurements were rejected as failing the chi-squared test (Manning et al. 2006a,b). It would be hard to conclude on this evidence that potential reservoir effects can be excluded in explaining the asserted discrepancy between a set 
of Santorini ${ }^{14} \mathrm{C}$ measurements and historical dates based on interconnections with Egypt and Cyprus. These now include the first appearance of Santorini (Theran) pumice at 15 sites in Egypt, the Near East, Cyprus, and the Dodecanese Islands in the historically appropriate Thutmoside levels and not $\sim 100$ yr earlier. All samples of pumice from earlier levels examined come from earlier eruptions at other Mediterranean volcanoes (M Bietak and M Bichler, personal communications of 6 July 2009; Bietak and Höflmayer 2007:17; Sterba et al. 2009). The Aegean High Chronology based on the disputed ${ }^{14} \mathrm{C}$ dates from Thera would require that Theran pumice lay on beaches uncollected for a century, and/or that no one collected it from Thera, Crete, or elsewhere for a century. Pumice has 14 known uses in antiquity, and was especially useful in metallurgy (Wiener and Allen 1998).

(b) Freshwater may be a source of ${ }^{14} \mathrm{C}$-deficient carbon (e.g. Glavatskaya et al. 2011), particularly where it has been in contact with volcanic or other gas emissions, thermal emission fields, or with limestone, a notorious source of such carbon (Mörner and Etiope 2002; Fischer and Heinemeier 2003; Fernandes et al. 2011). Rapp and Hill state the matter succinctly: "One potential influence is called the hardwater effect, where old or 'dead' carbon containing no ${ }^{14} \mathrm{C}$ becomes mixed with the carbon in an organic substance, thus making the sample appear older than it is. This is a special problem in areas saturated with groundwater that has been influenced by bedrock limestone" (Rapp and Hill 2006:149-50). Limestone may come into contact with soil directly as well, as a result of plowing or by other means. The island of Crete is composed largely of limestone, which creates a risk that some ${ }^{14} \mathrm{C}$ measurements of Cretan samples may provide erroneous early dates. The foregoing caution may apply, for example, to ${ }^{14} \mathrm{C}$ dates obtained from seeds found in a Late Minoan IB destruction at Chania in western Crete (Manning et al. 2009:309, confirmed by M Vlazaki, personal communication of 24 November 2008; E Hallager, personal communication of 24 November 2008). The dates reported were earlier than any other measurements from LM IB strata elsewhere in Crete (Housley et al. 1999). Farmland near Chania is watered by the Platanias River that runs from the White Mountains, named for their limestone composition, to the river mouth $13 \mathrm{~km}$ west of Chania. Homer tells us that the ancient Kydonians lived around the streams of Iardanos, the ancient name of the river (The Odyssey 3.292; I am grateful to E Hayes for reminding me of this passage). ${ }^{14} \mathrm{C}$ measurements from the bones of animals such as cattle, which consume large quantities of freshwater and grass dependent on freshwater, may also pose a problem in this regard.

(c) Deep seawater contains ${ }^{14} \mathrm{C}$-deficient carbon. Periodic upwelling of deep seawater releases ${ }^{14} \mathrm{C}$ deficient carbon into the atmosphere, where it may be absorbed by plants, thus skewing measurements from coastal sites toward older dates (Rapp and Hill 2006:153). Stuiver and Braziunas (1993) describe how irregular water-circulation oscillations of ${ }^{14} \mathrm{C}$-deficient water, some with a periodicity of 40-50 yr, operate globally. A recent study of 5-yr Japanese tree-ring segments of known dendrochronological date from $1060 \mathrm{BC}$ to $\mathrm{AD} 400$ found that for some periods the ${ }^{14} \mathrm{C}$ dates obtained differed significantly from the calibration curve dates. The authors suggested an "island effect" as a possible cause (Imamura et al. 2007; see also Ozaki et al. 2007, 2009). Sakamoto et al. (2009) note that with respect to ${ }^{14} \mathrm{C}$ dates from the Japanese Archipelago "possible local offsets of the curve cannot be ignored." Several studies have suggested the possibility of upwelling of ${ }^{14} \mathrm{C}$-deficient carbon in the Aegean in particular, either via the periodic exchange of water with the Black Sea, which is rich in ${ }^{14} \mathrm{C}$-deficient carbon (Keenan 2002), or the release of ${ }^{14} \mathrm{C}$-deficient carbon from underwater volcanic vents, one of which is located $7 \mathrm{~km}$ north-northeast of Thera (McCoy and Heiken 2000; for vents near Melos, see Pain 1999:41).

(d) Oceans and seas serve as carbon reservoirs at all times, even in the absence of vents or upwelling. Surface seawater has a ${ }^{14} \mathrm{C}$ activity lower than that of the atmosphere but greater than that of the deep ocean (Monge Soares et al. 2011:291). As a consequence, crustaceans and other sea 
creatures produce ${ }^{14} \mathrm{C}$ dates generally $\sim 400 \mathrm{yr}$ older than true dates, with additional offsets for certain regions (Stuiver et al. 1986; Reimer and McCormac 2002). Plants growing near estuaries or lagoons may potentially be affected as well (Petchey et al. 2011).

The largest-scale program of archaeological ${ }^{14} \mathrm{C}$ dating of a particular epoch and region ever undertaken, encompassing $2350{ }^{14} \mathrm{C}$ dates, has recently published its results, in volumes titled Gathering Time: Dating the Early Neolithic Enclosures of Southern Britain and Ireland. A chapter by Bayliss et al. states that "almost one in three of the radiocarbon dates considered in this volume are anomalously old because archaeologists selected their radiocarbon samples unwisely," citing old charcoal and movement of samples between contexts as potential causes (2011:45). Whether a riverine (hardwater) reservoir effect may also be present is not considered in the study.

\section{PROBLEMS OF CALIBRATION}

The problems of calibration are well understood in general terms in the ${ }^{14} \mathrm{C}$ community but much less well known in the archaeological world, and the specific extent of the difficulty with regard to the prehistory of the eastern Mediterranean is worthy of note. General challenges include (1) those inherent in comparing measurements from short-lived samples such as seeds, which may have a growing season measured in weeks, from plants with a growing season of a few months with 5- and 10 -yr tree segments, particularly considering that the amount of wood may vary significantly from year to year in the relevant calibration curve segment, and that decadal or semidecadal segments fit uncomfortably into the 11-yr sunspot cycle with its known effect on measurements; and (2) those caused by the irregular shape of the calibration curve, with long segments that are essentially flat rendering age discrimination within such segments impossible, and other areas where the calibration curve oscillates, resulting in 2 areas where uncalibrated ${ }^{14} \mathrm{C}$ measurements may fit. An example of the former occurs in the period $800-400 \mathrm{BC}$; an example of the latter occurs at the beginning of the Late Bronze Age in the Aegean, when measurements may intersect the calibration curve at various places between $\sim 1615$ and 1525 BC. German oak measurements made in 1998 were only about 10 ${ }^{14} \mathrm{C} \mathrm{yr}$ apart for calibrated ages of 1610 and $1530 \mathrm{BC}$ (and this is reflected as well in the IntCal98 measurements for 1615 and 1535 BC; Stuiver et al. 1998); the East Mediterranean Radiocarbon Intercomparison Project 2006 German oak measurements gave closely similar ${ }^{14} \mathrm{C}$ ages for determinations from the decades centered on 1605,1555 , and $1505 \mathrm{BC}$ and separately for 1585,1575 , and $1535 \mathrm{BC}$; and the Project measurement of the Anatolian junipers from Gordion gave similar ${ }^{14} \mathrm{C}$ ages at $3335 \mathrm{BP}$ for 1620,1570 , and $1540 \mathrm{BC}$, and only a minor difference of about $10^{14} \mathrm{C} \mathrm{yr}$ between 1600 and 1520 BC. Both IntCal04 and the Seattle German oak measurements show nearly identical ${ }^{14} \mathrm{C}$ ages at 1595 and $1525 \mathrm{BC}$ (Figure 2).

While the Gordion measurements are more geographically relevant to the dating of samples from Thera than Irish or German oak determinations, Thera and Gordion lie in separate meteorological regimes, with Gordion strongly affected by winds from the northeast (Reddaway and Bigg 1996: Figure 3; Keenan 2002:237, Figure 1). Accordingly, seasonal or other regional offsets may exist to some degree. In connection with the data depicted in Figure 2, it is worth noting that research in the course of establishing the 1998 calibration curve disclosed a mean difference of $24.2 \pm 6 \mathrm{yr}$ between Belfast measurements of Irish oak and Seattle measurements of German oak for the critical years 1700 to $1500 \mathrm{BC}$ (Wiener 2007). Manning et al. in their discussion of a ${ }^{14} \mathrm{C}$ measurement of a 3-yr twig from a tree preserved in the Volcanic Destruction Level on Thera, which produced a date consistent with the historical chronology, observe that the sample may "reflect short-term higher amplitude and/or frequency variation in atmospheric ${ }^{14} \mathrm{C}$ ages not seen in the IntCal04 record for the period, which is both based on 10-yr growth samples and smoothed" (2006b). The oscillation of the 
calibration curve in this area lies at the heart of the debate about the date of the Theran eruption. (Of course, oscillations may carry valuable information for wiggle-matching purposes; in such cases unsmoothed calibration curves may carry information erased by smoothing.)

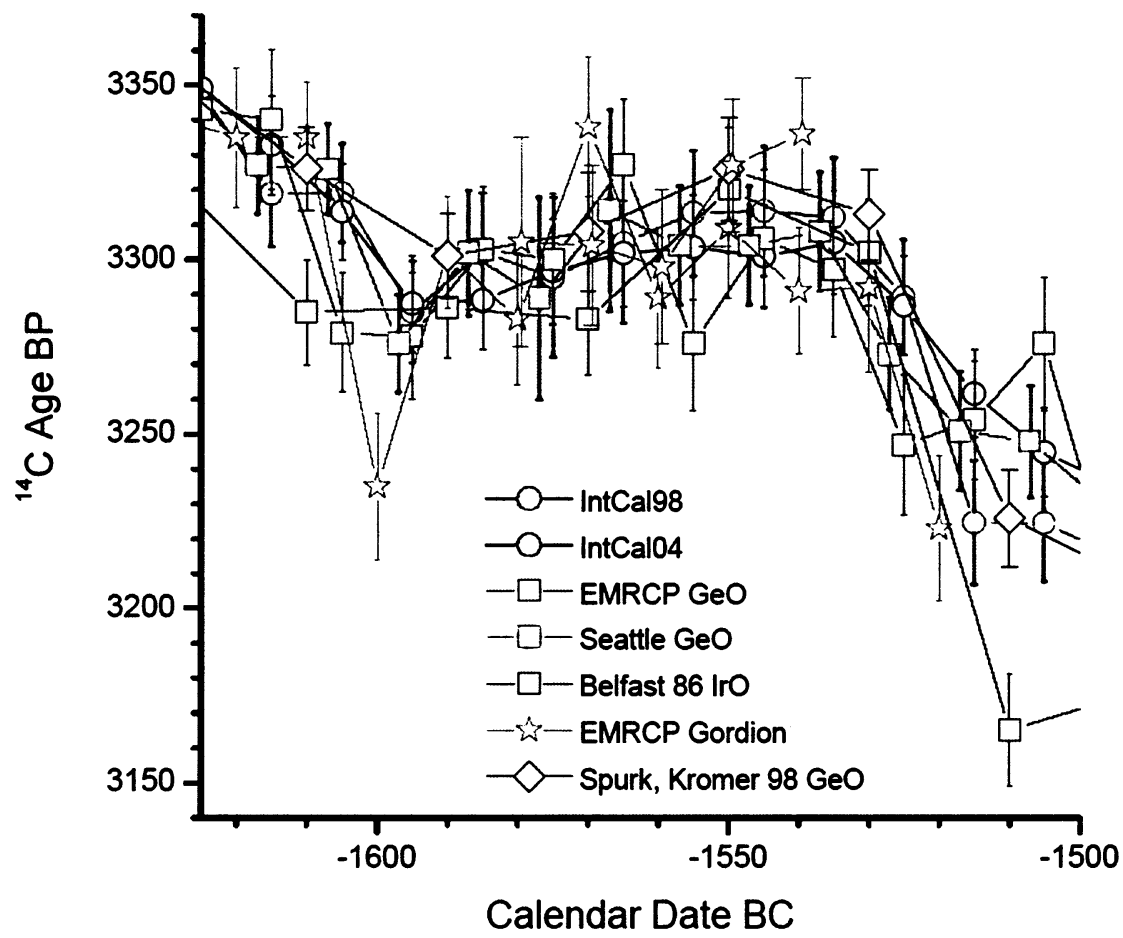

Figure 2 Comparison of the IntCal98 and IntCal04 calibration curves against the 2 major underlying data sets (the Seattle UWTEN data on German oak for this period, and the Belfast 1986 data on Irish oak [IrO]) and against the EMRCP data for German oak (GeO) and Gordion Juniper, and previous Heidelberg German oak data revised in 1998 (S Manning, personal communication).

\section{PROBLEMS OF ANALYSIS}

The statistical programs that convert ${ }^{14} \mathrm{C}$ measurements (which themselves may suffer distortion as noted above) into calendar dates contain 2 problems worth noting. First, stated results are based generally on the duration of intersection between the ${ }^{14} \mathrm{C}$ age range obtained and the relevant calibration curve measurements. In the case of intersection of the uncalibrated range with a 2-decadal segment in one area of an oscillating calibration curve and a 1-decadal segment in another, the result, ceteris paribus, would be stated as a $66.7 \%$ probability that the first intersection represents the correct calendar date, when in fact the shape of the curve at any particular point logically is largely irrelevant to the question. The Deputy Director of the Oxford Radiocarbon Laboratory has observed that in the example given there would exist "only a slight preference, if at all" for the area of 2-decade intersection (C Bronk Ramsey, personal communication of 7 September 2009, for which I am most grateful). Figure 3 illustrates the point.

The second problem applies in all cases. All calibration programs narrow stated error ranges in direct response to the number of measurements included - the more measurements, the narrower the range-without great regard to the consistency or inconsistency (even when substantial) of the mea- 


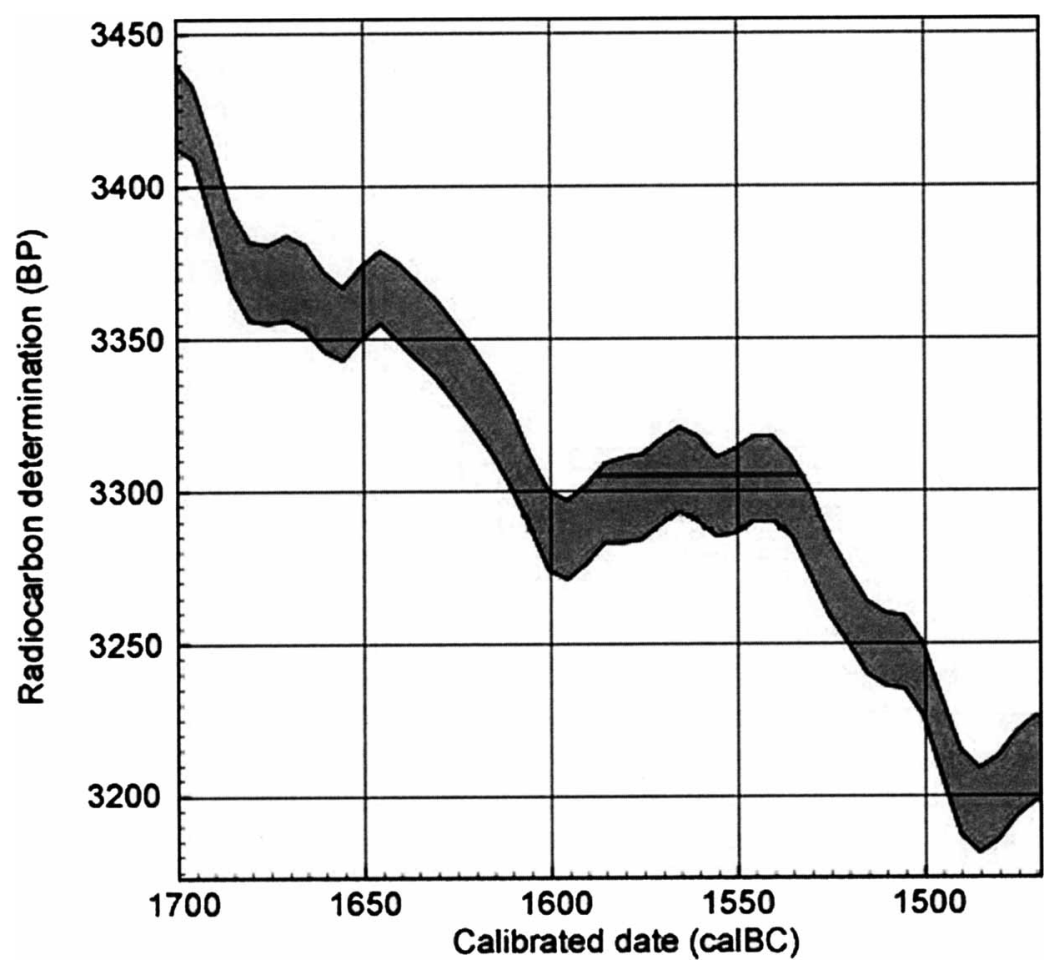

Figure 3 The horizontal bar represents the duration of contact of a measurement or combined series of measurements at 3305 BP with the calibration curve. The statistical "probability" of a date based on duration of contact differs from the "probability" of the resulting date (date range) as understood in general discourse.

surements themselves, provided the measurements meet the chi-squared test. (The OxCal v 4.1 program, described in Bronk Ramsey [2009], deals with disparate measurements of samples from the same event horizon by giving significantly less weight to measurements on the boundaries as distinguished from those in the center, while acknowledging that the definition of outliers is somewhat arbitrary. Differing statistical treatment of outliers can produce significantly different dates, as illustrated in Bronk Ramsey 2009:1029.) The chi-squared test itself, however, is logically dependent on the existence of Ward and Wilson Case I (Ward and Wilson 1978:20-1,30) which specifies that the method is appropriate only when the measurements are known to represent the same event (e.g. measurements from the bones of a single corpse). The test has often been utilized when the evidence is ambiguous in this regard, however. For example, the Ward and Wilson Case I analysis has been applied to seeds from the Volcanic Destruction Level at Thera (Manning et al. 2006a,b). Here, however, it is not clear whether some of the seeds were collected before the preliminary eruption that caused the populace to flee, or between that point and the final phase, during which some returned to try to rescue items of value, nor whether all the seeds measured came from the same location with regard to its distance from preexisting point, fault, or field of gas emissions capable of producing distorting reservoir effects. In any event, the Theran measurements produced ${ }^{14} \mathrm{C}$ age ranges whose central dates were as much as $250 \mathrm{yr}$ apart; dates for one species (grass pea) $215 \mathrm{yr}$ apart, as noted above, and dates for another (barley) $97 \mathrm{yr}$ apart (Manning et al. 2006b). The fact that 28 measurements (some of which preceded modern pretreatment and high-precision dating methods) were available resulted, however, in a claimed error range of only $\pm 7.5{ }^{14} \mathrm{C} \mathrm{yr}$. In a recent issue of Radio- 
carbon, Russell et al. (2011:280) in their discussion of errors associated with ${ }^{14} \mathrm{C}$ analysis procedures highlight "inappropriate errors placed on the age measurements," observing that "[t]his has to be a realistic estimate of the error and should not be based solely on counting statistics." Even apart from the likelihood of at least some reservoir effects on measurements of material from the volcanic island of Thera and perhaps also from the nearby sea, a known source of gas emissions (Pain 1999), the narrowness of the stated error range reflects the statistical conventions employed rather than the underlying reality.

C Bronk Ramsey has noted that there are 2 potential methods of addressing the problem within the OxCal program (personal communication, 30 December 2009). The first method is to insert what the archaeologist submitting the samples or other investigator regards as a minimum acceptable error range, based on her/his understanding of the nature of the database. In practice, this is never done, given the intrinsic unquantifiability of such a minimum and the fact that archaeologists seldom understand the complex statistical issues involved. The second method is to introduce an asymmetric adjustment to the error range (e.g. $+10 /-100)$ to reflect the excavator's understanding of the potential reservoir effects at the site. Such putative effects are also impossible to quantify, however, and no excavator would feel qualified to estimate them. Higham et al. (2005) note that measurement of bones poses particular problems with respect to reservoir effects, but that it is not possible to determine a suitable average correction factor. Steier and Rom (2000:183) observe that Bayesian programs "may result in dates with higher precision but lower accuracy and which are no longer in agreement with the true ages of the findings." In the case of the Theran seed measurements discussed above, a stated error range of (e.g.) \pm 35 instead of $\pm 7.5{ }^{14} \mathrm{C}$ yr would produce, as a consequence of the oscillation of the calibration curve, a calibrated range of approximately 1650-1515 $\mathrm{BC}$, which would encompass the well-supported archaeological date. A less than maximal claim of precision would thus result in a far higher likelihood of accuracy. Scott (2000:181) has noted that "Bayesian analysis is not a 'cure-all'; it has costs, not least the specification of the prior. This is not easy and even in those situations where we think we are not making any strong assumptions, there may be hidden complications." ${ }^{14} \mathrm{C}$ scientists coauthoring papers with archaeologists, anthropologists, and historians should be wary of special pleading intended to buttress a previously asserted position via the introduction of dubious priors in the form of arbitrary or insufficiently supported Bayesian boundaries that ignore contradictory data.

\section{PROBLEMS OF COMMUNICATION}

The final step in any ${ }^{14} \mathrm{C}$ analysis is the communication of its findings to the client and/or to the scholarly community in general. The degree of uncertainty inherent in ${ }^{14} \mathrm{C}$ dating, both in general and in particular regarding problems pertaining to the databank under consideration, should be clearly stated.

It is important in particular to note the difference in meaning of the term "probability" in ${ }^{14} \mathrm{C}$ terminology and in standard usage. In ${ }^{14} \mathrm{C}$ discourse, the term "probability" refers to the likelihood that ${ }^{14} \mathrm{C}$ measurements (which unless otherwise stated are presumed unaffected by reservoir effects, regional/ seasonal variation, calibration curve uncertainties, or other problems discussed above) fall within a particular range or ranges of ${ }^{14} \mathrm{C} \mathrm{yr} \mathrm{BP}$, and intersect whichever calibration curve is selected at a particular locus or loci. (The caveat previously noted respecting the doubtful relevance of the duration of intersection applies here.) It is worth noting that the OxCal, CALIB, Beta Analytic/Pretoria Laboratory, and Demokritos Laboratory calibration programs differ even with regard to the special ${ }^{14} \mathrm{C}$ usage of the term "probability." In the OxCal program, " $80 \%$ probability" means $80 \%$ out of $100 \%$, while in the CALIB program it means $80 \%$ out of the $2 \sigma$ standard deviation range of $95.4 \%$. Beta 
Analytic employs the Pretoria Calibration Procedure (Talma and Vogel 1993:317), which smoothes actual calibration curve measurements employing a spline, whereas IntCal04 and IntCal09 utilize a random walk model, but smooth the results by incorporating data from earlier and later decadal measurements (Reimer et al. 2004, 2009). (The 2 methods will frequently produce similar results. Both approaches acknowledge that the ${ }^{14} \mathrm{C}$ concentration in the atmosphere is unlikely to change as rapidly as differences in adjacent decadal measurements at various points would indicate.) The Demokritos Laboratory Athens program is different still, generally giving broader ranges but sometimes providing quite different results. Finally, it is important to note the difference between the highest probability density ranges now used for most purposes in ${ }^{14} \mathrm{C}$ calibration, and confidence ranges, generally defined in classical statistics as the confidence with which a null hypothesis may be rejected. There may be fully possible solutions outside the stated highest probability density range, although less probable than solutions within the range, given the assumptions incorporated into the analysis (C Bronk Ramsey, personal communication, 14 June 2011, for which I am most grateful).

The term "probability" is clearly used in a quite special sense in ${ }^{14} \mathrm{C}$ discourse. In standard usage, on the other hand, the term "probability" implies that all known sources of uncertainty, areas of insufficient knowledge, and contrary information (e.g. an archaeological context inconsistent with the ${ }^{14} \mathrm{C}$ dates) have been considered and an overall assessment stated. Accordingly, improvement in communication between ${ }^{14} \mathrm{C}$ scientists and historians, archaeologists, and other recipients of ${ }^{14} \mathrm{C}$ data is of critical importance. Archaeologists must make clear to ${ }^{14} \mathrm{C}$ scientists to whom they submit samples the precise nature of the contexts from which the samples have been taken, including the nature of the terrain with respect to possible reservoir effects and whether it is certain that samples from the same stratum represent the same point in time, absent which the application of Ward and Wilson Case I is not appropriate. ${ }^{14} \mathrm{C}$ scientists, for their part, should inform their clients of (1) the inherent problems of measurement and probabilistic analysis relevant to the degree of precision sought; (2) where material, the fact that probability estimates may differ slightly (but on occasion significantly) between laboratories due to differences in the statistical paradigms employed; (3) the problem of seasonal and/or regional variation, where pertinent to the degree of precision sought; (4) the nature of any uncertainty created by the shape of the calibration curve in a particular area, whether oscillating, horizontal, or sharply sloped (when small measurement differences may result in large differences in dates); and, in particular, (5) the potential in some geographic areas for distortion of dates as a result of reservoir effects stemming from the presence of ${ }^{14} \mathrm{C}$-deficient carbon in samples in areas containing volcanic gas emissions, geothermal fields, or general soil degassing, or groundwater affected by carbonates, or seawater from estuaries and lagoons, or where upwelling may have occurred. Lastly, ${ }^{14} \mathrm{C}$ laboratories should take special care to inform their clients that the meaning of the term "probability" in statistical analysis differs from its meaning in general usage and understanding.

Each year and each issue of Radiocarbon brings advances in the form of new data and improved understanding of the problem areas considered in this paper. At this time, unwarranted claims of accuracy and precision should be avoided in favor of caution and restraint in how ${ }^{14} \mathrm{C}$ analyses are presented.

\section{REFERENCES}

Arteca RN, Poovaia BW, Smith OE. 1979. Changes in carbon fixation, tuberization, and growth induced by $\mathrm{CO}_{2}$ applications to the root zone of potato plants. Science 205(4412):1279-80.
Bayliss A, van der Plicht J, Bronk Ramsey C, McCormac G, Healy F, Whittle A. 2011. Towards generational time-scales: the quantitative interpretation of archaeological chronologies. In: Whittle A, Healy F, Bayliss 
A, editors. Gathering Time: Dating the Early Neolithic Enclosures of Southern Britain and Ireland. Oxford: Oxbow. p 17-59.

Bietak M, Hölfmayer F. 2007. Introduction: high and low chronology. In: Bietak M, Czerny E, editors. The Synchronisation of Civilizations in the Eastern Mediterranean in the Second Millenium B.C. III: Proceedings of the SCIEM 2000-2nd EuroConference, Vienna, 28 May-1 June 2003. Vienna: Österreichische Akademie der Wissenschaften. p 13-23.

Bronk Ramsey C. 2009. Dealing with outliers and offsets in radiocarbon dating. Radiocarbon 51(4):1023-45.

Bruins HJ, van der Plicht J, Mazar A. 2003. Response to comment on ${ }^{114} \mathrm{C}$ dates from Tel Rehov: Iron-Age chronology, pharaohs, and Hebrew kings." Science 302(5645):568c.

Bruns M, Levin I, Münnich KO, Hubberten HW, Fillipakis S. 1980. Regional sources of volcanic carbon dioxide and their influence on ${ }^{14} \mathrm{C}$ content of present-day plant material. Radiocarbon 22(2):532-6.

Carapezza ML, Ricci T, Ranaldi M, Tarchini L. 2009. Active degassing structures of Stromboli and variations in diffuse $\mathrm{CO}_{2}$ output related to the volcanic activity. Journal of Volcanology and Geothermal Research 182(3-4):231-45.

Cardellini C, Chiodini G, Frondini F, Giaquinto S, Caliro S, Parello F. 2003. Input of deeply derived carbon dioxide in southern Apennine regional aquifers (Italy). Geophysical Research Abstracts 5:00927. URL: http: //www.cosis.net/abstracts/EAE03/09927/EAE03-J09927.pdf.

Chiodini G, Frondini F, Kerrick DM, Rogie J, Parello F, Peruzzi L, Zanzari AR. 1999. Quantification of deep $\mathrm{CO}_{2}$ fluxes from central Italy. Examples of carbon balance for regional aquifers and of soil diffuse degassing. Chemical Geology 159(1):205-22.

Chiodini G, Cardellini C, Amato A, Boschi E, Caliro S, Frondini F, Ventura G. 2004. Carbon dioxide Earth degassing and seismogenesis in central and southern Italy. Geophysical Research Letters 31: L07615, doi: 10.1029/2004GL019480.

Cramer MD. 2002. Inorganic carbon utilization by root systems. In: Waisel Y, Eshel A, Kafkafi U, editors. Plant Roots: The Hidden Half. New York: Marcel Dekker. p 699-714.

Dee M. 2010. Investigating the accuracy of radiocarbon dating in Egypt: checks with samples of known age. Paper Presented at Radiocarbon Dating \& Egyptian Chronology Symposium, Oxford, 17-18 March 2010.

Fernandes R, Nadeau M-J, Grootes PM, Hüls CM. 2011. Fishy chronologies. Paper presented at Radiocarbon and Archaeology, 6th International Symposium, Pafos, Cyprus, 10-15 April 2011.

Fischer A, Heinemeier J. 2003. Freshwater reservoir effect in ${ }^{14} \mathrm{C}$ dates of food residue on pottery. Radiocarbon 45(3):449-66.

Ford CR, Wurzburger N, Hendrick RL, Teskey RO. 2007. Soil DIC uptake and fixation in Pinus taeda seedlings and its $\mathrm{C}$ contribution to plant tissues and ectomycorrhizal fungi. Tree Physiology 27(3):375-83.

Frezzotti ML, Peccerillo A, Panza G. 2009. Carbonate metasomatism and $\mathrm{CO}_{2}$ lithosphere-asthenosphere degassing beneath the Western Mediterranean: an integrated model arising from petrological and geophysical data. Chemical Geology 262(1-2): 108-20.

Friedrich WL, Kromer B, Friedrich M, Heinemeier J, Pfeiffer T, Talamo S. 2009. Santorini eruption radiocarbon dated to $1627-1600 \mathrm{BC}$ : further discussion. In: Krzyszkowska O, editor. Cretan Offerings: Studies in Honour of Peter Warren. BSA Supplement 18. London: British School at Athens. p 293-8.

Gambardella B, Cardellini C, Chiodini G, Frondini F, Marini L, Ottonello G, Zuccolini MV. 2004. Fluxes of deep $\mathrm{CO}_{2}$ in volcanic areas of central-southern Italy. Journal of Volcanology and Geothermal Research 136(1-2):31-52.

Geisler G. 1963. Morphogenetic influence of $\left(\mathrm{CO}_{2}+\right.$ $\mathrm{HCO}_{3}-$ ) on roots. Plant Physiology 38:77-80.

Glavatskaya EV, Kovalyuh NN, Skripkin VV. 2011. Features of the reservoir effect formation in fluvial ecosystems of the Pripyat' and Dnieper rivers (Ukraine). Poster presented at Radiocarbon and Archaeology, 6th International Symposium, Pafos, Cyprus, 10-15 April 2011.

Higham T, Anderson A, Bronk Ramsey C, Tompkins C. 2005. Diet-derived variations in radiocarbon and stable isotopes: a case study from Shag River Mouth, New Zealand. Radiocarbon 47(3):367-75.

Housley RA, Manning SW, Cadogan G, Jones RE, Hedges REM. 1999. Radiocarbon, calibration, and the chronology of the Late Minoan IB phase. Journal of Archaeological Science 26(2):159-71.

Imamura M, Ozaki H, Mitsutani T, Niu E, Itoh S. 2007. Radiocarbon wiggle-matching of Japanese historical materials with a possible systematic age offset. Radiocarbon 49(2):331-7.

Keenan DJ. 2002. Why early-historical radiocarbon dates downwind from the Mediterranean are too early. Radiocarbon 44(1):225-37.

Keenan DJ. 2004. Radiocarbon dates from Iron Age Gordion are confounded. Ancient West \& East 3:100-3.

Kromer B, Manning SW, Kuniholm PI, Newton MW, Spurk M, Levin I. 2001. Regional ${ }^{14} \mathrm{CO}_{2}$ offsets in the troposphere: magnitude, mechanisms, and consequences. Science 294(5551):2529-32.

Kromer B, Manning SW, Friedrich M, Talamo S, Trano N. $2010 .{ }^{14} \mathrm{C}$ calibration in the 2 nd and 1 st millennia BC-Eastern Mediterranean Radiocarbon Comparison Project (EMRCP). Radiocarbon 52(3):875-86.

Levin I, Bösinger R, Bonani G, Francey RJ, Kromer B, Münnich KO, Suter M, Trivett NBA, Wölfli W. 1992. Radiocarbon in atmospheric carbon dioxide and methane: global distribution and trends. In Taylor RE, Long AA, Kra RS, editors. Radiocarbon after Four Decades: An Interdisciplinary Perspective. New York: Springer-Verlag. p 503-18. 
Levin I, Hesshaimer V. 2000. Radiocarbon-a unique tracer of global carbon cycle dynamics. Radiocarbon 42(1):69-80.

Manning SW, Kromer B, Kuniholm PI, Newton MW. 2001. Anatolian tree rings and a new chronology for the East Mediterranean Bronze-Iron ages. Science 294(5551):2532-5.

Manning SW, Bronk Ramsey C, Kutschera W, Higham T, Kromer B, Steier P, Wild EM. 2006a. Chronology for the Aegean Late Bronze Age 1700-1400 B.C. Science 312(5773):565-9.

Manning SW, Bronk Ramsey C, Kutschera W, Higham T, Kromer B, Steier P, Wild EM. 2006b. Supporting online material for Chronology for the Aegean Late Bronze Age 1700-1400 B.C. Science 312(5773):565. URL: http://www.sciencemag.org/cgi/content/full/ 312/5773/565/DC1.

Manning SW, Bronk Ramsey C, Kutschera W, Higham T, Kromer B, Steier P, Wild EM. 2009. Dating the Santorini/Thera eruption by radiocarbon: further discussion (AD 2006-2007). In: Manning SW, Bruce MJ, editors. Tree-Rings, Kings, and Old World Archaeology and Environment. Cornell Dendrochronology-Archaeology Conference in Honor of Peter Ian Kuniholm. Oxford: Oxbow Books. p 299-316.

Manning SW, Kromer B, Bronk Ramsey C, Pearson CL, Talamo S, Trano N, Watkins JD. 2010. ${ }^{14} \mathrm{C}$ record and wiggle-match placement for the Anatolian (Gordion area) juniper tree-ring chronology $\sim 1729$ to $751 \mathrm{cal}$ $\mathrm{BC}$, and typical Aegean/Anatolian (growing season related) regional ${ }^{14} \mathrm{C}$ offset assessment. Radiocarbon 52(4):1571-97.

McCormac FG, Baillie MGL, Pilcher JR, Kalin RM. 1995. Location-dependent differences in the ${ }^{14} \mathrm{C}$ content of wood. Radiocarbon 37(2):395-407.

McCormac FG, Hogg AG, Blackwell PG, Buck CE, Higham TFG, Reimer PJ. 2004. SHCal04 Southern Hemisphere calibration, 0-11.0 cal kyr BP. Radiocarbon 46(3): 1087-92.

McCoy FW, Heiken G. 2000. The Late-Bronze Age explosive eruption of Thera (Santorini), Greece: regional and local effects. In: McCoy FW, Heiken G, editors. Volcanic Hazards in Human Antiquity. Geological Society of America Special Paper 345. London: Geological Society of America. p 43-70.

Minissale A, Magro G, Vaselli O, Verrucchi C, Perticone I. 1997. Geochemistry of water and gas discharges from the Mt. Amiata silicic complex and surrounding areas (central Italy). Journal of Volcanology and Geothermal Research 79(3-4):223-51.

Monge Soares AM, Matos Martins JM, Cardoso JL. 2011. Marine radiocarbon reservoir effect of coastal waters off Cape Verde Archipelago. Radiocarbon 53(2):289-96.

Mörner N-A, Etiope G. 2002. Carbon degassing from the lithosphere. Global and Planetary Change 33(1-2): 185-203.
Ozaki H, Imamura M, Matsuzaki H, Mitsutani T. 2007. Radiocarbon in 9th to 5th century BC tree-ring samples from the Ouban 1 archaeological site, Hiroshima, Japan. Radiocarbon 49(2):473-9.

Ozaki H, Sakamoto M, Imamura M, Matsuzaki H, Nakamura $\mathrm{T}$, Kobayashi $\mathrm{K}$, Itoh S, Niu E, Mitsutani $\mathrm{T}$. 2009. Radiocarbon dates of Japanese tree rings for 1060 BC-AD 400. In: Proceedings of the 20th International Radiocarbon Conference, Big Island, $\mathrm{Ha}$ waii, 31 May-5 June 2009, Abstracts of Papers.

Pain S. 1999. Vents de Milos. New Scientist 163(2197): 38-41.

Pasquier-Cardin A, Allard P, Ferreira T, Hatte C, Coutinho R, Fontugne M, Jaudon M. 1999. Magmaderived $\mathrm{CO}_{2}$ emissions recorded in ${ }^{14} \mathrm{C}$ and ${ }^{13} \mathrm{C}$ content of plants growing in Furnas Caldera, Azores. Journal of Volcanology and Geothermal Research 92(1-2):195-208.

Petchey F, Clark G, Ulm S. 2011. Radiocarbon dating marine shells: an investigation of $\Delta R$ in the Pacific and problems encountered. Paper presented at Radiocarbon and Archaeology, 6th International Symposium, Pafos, Cyprus, 10-15 April 2011.

Rapp GR, Hill CL. 2006. Geoarchaeology: The EarthScience Approach to Archaeological Interpretation. New Haven: Yale University Press.

Reddaway JM, Bigg GR. 1996. Climatic change over the Mediterranean and links to the more general atmospheric circulation. International Journal of Climatology 16(6):651-61.

Reimer PJ. 2001. A new twist in the radiocarbon tale. Science 294(5551):2494-5.

Reimer PJ, McCormac FG. 2002. Marine radiocarbon reservoir corrections for the Mediterranean and Aegean seas. Radiocarbon 44(1): 159-66.

Reimer PJ, Baillie MGL, Bard E, Bayliss A, Beck JW, Bertrand CJH, Blackwell PG, Buck CE, Burr GS, Cutler KB, Damon PE, Edwards RL, Fairbanks RG, Friedrich M, Guilderson TP, Hogg AG, Hughen KA, Kromer B, McCormac G, Manning S, Bronk Ramsey C, Reimer RW, Remmele S, Southon JR, Stuiver M, Talamo S, Taylor FW, van der Plicht J, Weyhenmeyer CE. 2004. IntCal04 terrestrial radiocarbon age calibration, 0-26 cal kyr BP. Radiocarbon 46(3):1029-58.

Rogie JD. 1996. Lethal Italian carbon dioxide springs key to atmospheric $\mathrm{CO}_{2}$ levels. Penn State Earth and Environmental Systems Institute. News and Events: News Archives. URL: http://www.eesi.psu.edu/ news_events/archives/Lethal.shtml.

Rogie JD, Kerrick DM, Chiodini G, Frondini F. 2000. Flux measurements of nonvolcanic $\mathrm{CO}_{2}$ emission from some vents in central Italy. Journal of Geophysical Research 105(B4):8435-45.

Russell N, Cook GT, Ascough PL, Scott EM, Dugmore AJ. 2011. Examining the inherent variability in $\Delta R$ : new methods of presenting $\Delta R$ values and implications for MRE studies. Radiocarbon 53(2):277-88. 
Sakamoto M, Fujio S, Kobayashi K, Ozaki H, Imamura M. 2009. Radiocarbon dates of Japanese tree rings for 1060 BC-AD 400. Paper presented at the 20th International Radiocarbon Conference, Big Island, Hawaii, 31 May-5 June 2009.

Scott EM. 2000. Bayesian methods: What can we gain and at what cost? Radiocarbon 42(2): 181.

Scott EM, editor. 2003. The Third International Radiocarbon Intercomparison (TIRI) and the Fourth International Radiocarbon Intercomparison (FIRI), 19902002: results, analyses, and conclusions. Radiocarbon 45(2):135-328.

Shore JS, Cook GT, Dugmore AJ. 1995. The ${ }^{14} \mathrm{C}$ content of modern vegetation samples from the flanks of the Katla Volcano, southern Iceland. Radiocarbon 37(2): 525-9.

Skok J, Chorney W, Broeker WS. 1962. Uptake of $\mathrm{CO}_{2}$ by roots of xanthium plants. Botanical Gazette 124(2): 118-20.

Splittstoesser WE. 1966. Dark $\mathrm{CO}_{2}$ fixation and its role in the growth of plant tissue. Plant Physiology 41(5): 755-9.

Steier P, Rom W. 2000. The use of Bayesian statistics for ${ }^{14} \mathrm{C}$ dates of chronologically ordered samples: a critical analysis. Radiocarbon 42(2): 183-98.

Sterba JH, Foster KP, Steinhauser G, Bichler M. 2009. New light on old pumice: the origins of Mediterranean volcanic material from ancient Egypt. Journal of Archaeological Science 36(8):1738-44.

Stolwijk JAJ, Thimann KV. 1957. On the uptake of carbon dioxide and bicarbonate by roots and its influence on growth. Plant Physiology 32(6):513-20.

Stuiver M, Braziunas TF. 1993. Sun, ocean, climate and atmospheric ${ }^{14} \mathrm{CO}_{2}$ : an evaluation of causal and spectral relationships. The Holocene 3(4):289-305.

Stuiver M, Pearson GW, Braziunas TF. 1986. Radiocarbon age calibration of marine samples back to 9000 cal yr BP. Radiocarbon 28(2B):980-1021.

Stuiver M, Reimer PJ, Bard E, Beck JW, Burr GS, Hughen KA, Kromer B, McCormac G, van der Plicht J, Spurk M. 1998. IntCal98 radiocarbon age calibration, 24,000-0 cal BP. Radiocarbon 40(3):1041-83.

Sveinbjörnsdóttir ÁE, Heinemeier J. 2011. The controversy of the settlement time of Iceland. Paper presented at Radiocarbon and Archaeology, 6th International Symposium, Pafos, Cyprus, 10-15 April 2011.

Talma AS, Vogel JC. 1993. A simplified approach to calibrating ${ }^{14} \mathrm{C}$ dates. Radiocarbon 35(2):317-22.

Taylor RE. 1997. Radiocarbon dating. In: Taylor RE, Aitken MJ, editors. Chronometric Dating in Archaeology. Advances in Archaeological and Museum Science 2. New York: Plenum Press. p 65-96.

Ward GK, Wilson SR. 1978. Procedures for comparing and combining radiocarbon age determinations: a critique. Achaeometry 20(1):19-31.

Wiener MH. 2007. Times change: the current state of the debate in Old World chronology. In: Bietak M, Czerny $\mathrm{E}$, editors. The Synchronisation of Civilisations in the Eastern Mediterranean in the Second Millennium B.C. III. Proceedings of the SCIEM 2000-2nd EuroConference, Vienna, 28 May-1 June 2003. Vienna: Verlag der Österreichischen Akademie der Wissenschaften. p 25-47.

Wiener MH. 2010. A point in time. In: Krzyszkowska O, editor. Cretan Offerings: Studies in Honour of Peter Warren. BSA Supplement 18. London: British School at Athens. p 367-94.

Wiener MH, Allen JP. 1998. Separate lives: the Ahmose Tempest Stela and the Theran eruption. Journal of Near Eastern Studies 57(1):1-28.

Yorgalevitch CM, Janes WH. 1988. Carbon dioxide enrichment of the root zone of tomato seedlings. Journal of Horticultural Science 63:265-70. 